\title{
ISLAMIC EDUCATIONAL PATTERN AND STREET CHILDREN CARE
}

\author{
Hasanuddin \\ hasnafiaunillah@gmail.com
}

\begin{abstract}
This reseach aimed to determine the background of the emergence of street children stayed Puri Indah shelter house of Sidoarjo. In addition, this reseach also aimed to determine the pattern of communication that is formed, the steps of assistance and the factors driving and inhibiting the implementation of street child educational pattern. Qualitative descriptive research was done by collecting data using interviews, observation, literature study and documents. The informant was chosen by using purposive sampling. Analytical techniques used interactive analysis model which includes data collection, data reduction, data presentation and conclusion. From the research results could be seen that the cause of the emergence of street children because of economic factors, family disorganization, street family dynasties and customs tangent with street children. Responding to this Puri Indah shelter house of Sidoarjo made education pattern to street children. The communication pattern formed in this program is the formal communication seen at the time of routine learning and field study, nonformal communication seen in activity outside school and is more relaxed. Non verbal communication seen from the response of limbs of students. In connection with the interaction, there emerged a linear communication model, transactional and intransactional. The Puri Indah shelter house of Sidoarjo has innovative teaching methods both conducted by teachers and involving the active role of students. In order for our program to be more qualified, Puri Indah shelter house of Sidoarjo provided various facilities for students such as supporting books, bicycle, stationery library and paying attention to their nutrition. Nevertheless there was no doubt there were some weaknesses such as the arrogant nature of the students, the credibility of teachers who had not maximized, the limited facilities of infrastructure. However it could be overcome with the spirit of all elements and support of all parties.
\end{abstract}

Keywords: Education, Parenting, Street Children

\section{A. Introduction}

The phenomenon of street children in Indonesia is an issue that requires the special attention of all elements of society. The number of street children in Indonesia increases from year to year. In 2010, the number of street children in Indonesia is estimated to reach 200,000 children and in 2012 increased to 230,000 children.

According to de Moura, street children can be divided into two groups, namely children working on the streets and children living on the streets. ${ }^{1} \quad$ Based on the survey

1 De Moura,S. L "The sosial contructiaon of the street chlidren: configuration and implication" Britisth Journal of social Work :2002. vol 32 pp 253-367. conducted by the Ministry of Women Empowerment, the reason for working children is to help the work of parents (71\%), be forced to help parents $(6 \%)$, increase school fees (15\%), and because they want to live freely, for pocket money, and others (33\%).

The child is the future investment of the nation. One country's progress is determined by the quality of its young generation, which can be seen from children's conditions today. Thus street children are also a valuable asset of the state that should be empowered, cared for and educated for a higher value point. It is also in line with the 1945 Constitution article 34 verse 1 stating that the poor and neglected children are kept by the state. So street children have the right to be nurtured by the state. However in 
reality, street children are displaced and do not get their rights. Education is one of the important and supportive sectors in the development process, because it has the task of preparing human resources in supporting the development of the country. The regulation of the right to education is regulated in Article 31 of the 1945 Constitution. In paragraph (1) it is stipulated that everyone is entitled to education. This Article means that the state is obliged to fulfill the right to education for every citizen without exception, regardless of race, race, religion, or even social and economic circumstances.

In practice, the fulfillment of the right to education becomes very difficult and even tends not to perform well. Different types of education tend to be formal education, which uses uniforms with study hours as well as a predetermined and flat-ranged curriculum on a national scale. In addition, formal education is very expensive and difficult to reach by the middle to lower economic community.

This education system is very difficult to accept by street children who have to work to help the family economy. In this case, the state through Law Number 20 Year 2003 on National Education System stipulates that in order to fulfill the citizens' rights on education, especially street children, it can be implemented through non formal education system.

Non-formal education is as a non-institutionalized, institutionalized and non-institutional education that is an alternative to solving the problem of street children. Through non-formal education in the form of art, it would create a skilled workforce and there are new jobs because with the nonformal education, social institutions such as shelter homes provide their provisions in the form of skills for their future. One of the non formal education initiated to meet the educational needs of street children in Surabaya area is Sanggar AlangAlang. Sanggar Alang-alang was established as an alternative school or an out-of-school education dedicated to the children of poor families, orphans and abandoned children. In Sanggar Alang-alang there are 3 programs that are Talented Child and Arts Sports Guidance, Spiritual / Religious Mental Guidance and Mother and Child Guidance or Bimbingan Ibu dan Anak (BIAN).

Management is an integral component and can not be separated from the education process as a whole. The reason without management may not be the goal of education can be realized optimally, effectively and efficiently in order to grow this awareness of the importance of management.

According to Law number 20 year 2003 article 1 clause 4 on the national education system, learners are members of the community who seek to develop their own potential through the learning process available on the path, ladder, and certain types of education. $^{2}$

To achieve the goal of quality education required education management that can mobilize all educational resources. Management education is related to the management of learners whose contents are the management and implementation.

Management of learners is to make and arrange the activities that relates to the learner start to enter until the release of the learners from a

2 E. Mulyana, Manajemen berbasis kopetensi dan aplikasinya, (bandung :Rosdakarya,2003), 20. 
school. Student management is not only in the form of recording student data, but covers a broader aspect that can operatively help the growth and development of learners through the process of education in school.

\section{B. Research Method}

\section{Research Approach}

To get a substantive understanding of the problem of Islamic Education Pattern and Street Child Care then this research uses qualitative approach. Qualitative approach tends to use inductive analysis, where research process and giving meaning to data and information more highlighted, with the main characteristic of this approach is a form of narrative that is creative, deep and naturalistic.

In this connection Arief Furchan (1999: 22) explains as follows: The qualitative method is "the research process that produces descriptive data, speech or writing or observable behavior of the people themselves, in our opinion this approach instantly shows the settings and the individuals in the setting as a whole. The subject of investigation either in the form of an organization or an individual does not narrow down to a separate variable or a hypothesis but is seen as part of a whole ".

From the opinion above, it can be said that the qualitative approach "trying to get descriptive data, speech or writing and behavior that can be observed.

In this study uses qualitative approach with reasons that refer to several reasons as to which which is put forward by. Margono (2000: 37), among others:

1. To cope with the amount of information lost, as experienced by qualitative research so that the essence of existing concepts in the data can be revealed.

2. To overcome the tendency to dig up empirical data with the aim of proving the hypothesis of the result of the hypothesis that is prepared previously based on deductive thinking as in quantitative thinking.

3. To overcome the trend of limiting the previous variables, as in quantitative research whereas the problems and variables in social problems are very complex.

4. To cope with rough indices as in quantitative research using empirical enumeration measurements, whereas the core is actually in the concepts arising from the data.

In addition to the above reasons, in this study uses a qualitative approach due to several important things, among others: first, because the background research is not homogeneous, second, because this research wants to reveal the data with what is in accordance with the findings in the field of Islamic Education Pattern and Street Child Care.

\section{Data Source}

The data source in this study is the subject from which the data is obtained.

Sources of data in this study is the board of shelter House from chairman to section section existing Determination of data sources is based on the assumption that the subject of the data source to know the implementation of the process Pattern pendidkan. The type of data to be obtained is on the Pattern of Islamic Education and Child Care Street. constraints of Education Pattern and solutions to overcome obstacles in 
educating Street Children and other data needed to complete the preparation of the thesis.

\section{Data Collection Procedures}

In qualitative research, the researcher as well as function as the main instrument that plunge the field and also try to collect the data through observation and interview and interview in more detail data collecting technique used in this research are:

\section{a. Observation Method.}

Observation is a data collection tool that is done by observing and systematically recording the symptoms investigated. (Supardi, 2006: 88). Similarly, Yehoda et al (2006: 89) describes observations as being a good data collection tool if:

1) Served on the purpose of research.

2) Systematically planned

3) Recorded and associated with common propositions

4) Printed and controlled its validity, reliability, and thoroughness.

In this method, the researcher goes directly to observe directly the principal leadership, activities and social phenomena that occur as a result of the implementation of the principal's leadership.

The data required in this observation method is to observe directly the principal's leadership, the implementation of teaching and learning process, the activities of the teacher, the activities of the students, and the activities undertaken by the administration in order to create a good and conducive learning process.

\section{b. Interview Method}

This method is also called the interview method, which is a method of collecting data that is done through a question and answer directly with the data source.
Margono (2003: 165) argues that: "interviews are a means of gathering information by asking questions orally, to be answered orally as well, the main feature of the interview is direct contact with face-to-face information seekers with information sources".

In this in-depth interview conducted by researcher on informants who became the object of this research are school leaders, teachers, students and administration. This interview aims to obtain information that is relevant to the principal issue of research is the leadership of the principal in improving the implementation of teaching and learning process.

Interview data required in this research, that is about Pattern of Islamic Education and care of Street Children, the obstacles faced by Housing Officer, solution to overcome the constraints of management and data that is relevant to the subject matter of the researcher.

\section{c. Documentation Method - Research} Method

In qualitative research there are sources of non-human data such as documents, photographs and statistical materials.

This method of documentation is one of the easiest forms of data collection, because the researcher only observes inanimate objects and if it is easy to revise it because the data source is fixed and unchanged.

According to Arikunto (2000: 234) the method of documentation is: "looking for data about things or variations in the form of notes, transcripts, books, newspapers, news magazines, magazines, inscriptions, minutes, report cards, legends and so forth". 
Documents required in this study include the organizational structure of school institutions, teacher data, students, administrative staff data, facilities and infrastructure owned by shelter and other data required to complete the preparation of this thesis.

\section{Data Analysis}

Analysis of qualitative research data has been basically done since the beginning of research activities until the end of the study. In this way it is hoped that there is consistency of data analysis as a whole. Since considering this research is descriptive, then used analysis of philosophical data or logic that is inductive analysis.

Inductive method is the method of thinking by drawing conclusions from the data that is special. As explained by Sutrisno, namely: "... Inductive thinking departs from special facts, concrete events, then from special facts or events, it is concretely drawn generalizable generalizations general". (Sutrisno, 1986: 42).

In this research, an inductive method is used to draw a conclusion on the things or events of the data that have been collected through observation, interviews and documentation, which can be generalized (drawn towards general conclusions), it is clear that this inductive method to assess the factsempirical facts are found and then matched with existing theories.

\section{Research Result}

\section{Supporting Factor and Inhibitors of Street Children Education}

In the implementation of assistance, especially education by Puri Indah Shelter House of Sidoarajo there are supporting and inhibiting factors, internally and externally. has a supporting and inhibiting factors. The details of inhibiting and supporting factors in shelter house are as follows:

In implementing the shelter house program, especially education programs for street children, Shelter House has internal and external supporting and inhibiting factors.

a) Supporting Factors

Internal support factors come from their own shelter house, while external supporting factors derived from the environment around the shelter, both community, volunteers, and government. One of the internal supporting factors that there is still a motivation to learn from children. As Fsl has said, a volunteer of educators: "... Yes if the supporters are, there is still a child who still wants to read the holy quran that they asked, yes at least there is still a motivation to learn, but yes it is".

The Fsl's statement is in line with what mrs Ek said as the administrative worker: "If the supporters are still the children who want to read the holy quran, so it motivates the tutor to teach, the facility is good enough".

Based on these two opinions can be seen that there are two internal support factors, namely derived from individual street children themselves, as well as adequate facilities in the shelter house infrastructure. Internal factors of the individual street children in question is still a child who has the motivation to learn. While the facilities and infrastructure of a halfway house is sufficient for street children and in the learning process. As stated by Mr. Syd as the leader of the shelter house, as follows: "Yes if the facility, I think if in the shelter house is standard, there is a bedroom that is not just on the floor so, there is a mattress, soap, clothes there, our health guarantee 
with health insurance, our school also find scholarship. If standardization in general I see everywhere Alhamdulillah yes it is extraordinary, I am ready in 24 hours to watch them, the others are not there like that..... If for our education here there are reading books, we also provide stationery for students, if for the skill we also have a computer, sewing machine is also there, yes it maybe only that but it quite helpful ".

Based on the opinion of the leader about the abandoned shelter house above, it can be seen that the shelter house has provided various facilities for street children, both from the fulfillment of basic needs and the fulfillment of children's education needs.

Besides the internal support factors, there are external support factors. These external factors include volunteers, community support around shelter house, schools, up to government support. As AR has pointed out, a social worker: "The supporters of our colleagues are equally sharing, caring about the future of the children, they are supportive, and they are really in totality to come here without any fee, even they reach out to his own cone, so we follow the spirit. Most of them are from UGM, KCP, UAD, because they have nothing to do but only a help. "

Similarly, the statement expressed by Mr. Syd, the leader of the abandoned house: "Skills are sometimes here, my friends regularly from the faculty of da'wah UIN, from the scouting of UMY, and some friends of UMY. Many times for key chain skills, then from UAD pharmaceuticals. And if the discharge is from the social offices of the province or city who want to provide training and working capital ".

Based on the above statement of social workers and homeowners, it is well known that these volunteers provide science and knowledge to street children without reward. In addition to providing knowledge and knowledge volunteers also provide opportunities for street children to work. As expressed by Mr. Syd as the leader of the shelter house: "..may be their friends of volunteer who may open the motorcycling business, then catering, that refers to the culinary, the children are involved to work in cooking, dishwashing, and so forth like that. .... there are also the companies or stores, souvenir shops. ... There are the clues that the children may go there or not, and we recommend to his boss or her boss, it is important that someone will accept them, willing to accommodate, it is a great appreciation to alleviate them. "

Based on the above statement by the leader of the shelter house, it can be seen that not only the volunteers provide opportunities for street children, but also the companies, LSM, and related agencies have a stake in off-roading the street children from their economy through job opportunities.

In addition to the above supporting factors, external support factors and also come from the community, especially the community participation around the shelter house. As stated by Mr. Syd, the leader of the shelter house: "Alhamdulillah the community participation is very good. Since without their acknowledging, being involved in youth combatants, then TPA, and then involving the event of devotion work and so on, with the citizens that children also feel their position there, and it is 
indispensable for them, in fact it is. If he still thinks that he is a child who needs attention, it will be easy to change their behavior, they are also considered to exist, if they are considered still nothing they will not come back.

In addition to volunteer and community factors, external support factors also come from schools that wants to accept street children as learners. As explained by Mr. Syd, the leader of the shelter house: "if the factor of the school I think that the school in Jogja even though the name of the student city but there are schools that would be liquidated if not get students, so the principal with then come here to ask the children .... And it is very supportive to children ....".

With the existence of schools that wants to accept street children will facilitate access to the children education, especially for the formal education. So the right of street children to get education can be accepted by the children.

In addition to some of the external support factors above, one of the most important supporting factors is the supporting factor of the government, namely the existence of Perda no. 6 Year 2011 on PAHJ (Rules of Street Living Children). As stated by Mr. Syd, the leader of the shelter house: "..... so Alhamdulillah in 2011 last time there was a draft of RAPERDA about children living in the street. Therefore Alhamdulillah we concentrate on the children who live in the street also there was the policy in the armed forces there, and alhamdulillah it is the only local regulation that exist all over Indonesia $"$.

While specifically for educational issues, the government also provides support by issuing PP no. 17 Year 2010 on the Management and Implementation of Education. With the regulation, the shelter house has a clear legal rule.

Based on some opinions above, it can be concluded that there are two supporting factors namely internally and externally. Internal support factors consist of still a handful of children who have the motivation to learn, as well as sufficient infrastructure facilities for street children. While external support factors consist of volunteers, community environment, schools and related to LSM, and government.

b) Inhibiting Factors

In the implementation of street children education, it turns out the shelter house still find obstacles. This inhibiting factor is divided into two factors, namely internal inhibiting factors and external inhibiting factors. One of the internal inhibiting factors is the independence of the street children. As disclosed by Mr. Syd as the leader of the shelter house: "The inhibiting factor is indeed because we segment of street children can not be independent like a normative child, should need guidance and intensive direction, if the child in decision making in household regulation that's it. Arrangement of shelter homes, it turns out the participation is still minimal, different if we look to school let alone the favorite schools and so on that be noted both in the opinion and also in faclitating their talent, and art and so it exists, but if the street children are still very minimal, so in the sense here not only the children's rights are fulfilled but it is our duty as a street children that must be no interfere with the environment and so on, he also must have the same norms that must be 
adhered to in society such as it, it turns out the internal factors of children who want to normative it is rather difficult.

The statement of Mr. Syd above, it can be seen that the independence means the independence of the children that obey the rules. Unlike the normative children, street children feel free and away from the rules. Likewise, Fsl is as the volunteer of an educator: "there are some kind of the obstacle. ... it may be from his attitude, rich for example $\mathrm{X}$ that he is a good fighter but his behavior likes thieves to take a bike. Then it may be the $\mathrm{Y}$ that he was not too able to read the holy quran, but he has a good progress in every Sunday can be increased. Actually the others may be increased but it may be slower. The obstacles that may be often here, but their character still want to be free and continue if in learning they get little bit lazy. If they are asked to read the holy quran, they will do ".

Likewise, Mrs. Ek's statement is an administrative worker: "If the children's obstacles are lazy, the children's interest in learning is low, free because they are accustomed to the streets, we have maximized the program but the children do not follow the activities, their motivation is less we have tried as much as possible to motivate them ".

Likewise, which was sent by Mr. Syd, the leader of the shelter house: "... we've tried outbound, there are tutoring, $\mathrm{KCP}$ children in daily activity that is as the children's respon. There are some friends from Australia who teach English, but the response may be from 10 children that is only from 2 children, $2 \%$ only who wants to join but the others do not participate at all. It is the same with formal education, skill education that I used to practiced the knowledge can be used to work with the science. Therefore they are able to do it, but now the laziness of the children are getting more ... . that happens, so it is from the internal factor alone that is the children ".

Based on these three opinions can be seen that the internal inhibiting factors derived from street children themselves. Street children who used to live free on the streets without any norms or values that govern their lives make them difficult to return normatively. In addition to these inhibiting factors, other inhibiting factors are the laziness happens to the street children, low learning interest, and motivation to follow various activities are still small. As expressed by Mr. Syd, the leader of the shelter house: ".... But indeed the children who are now from the year 2010, 2011 are already I feel so upset why the children and not really the other ones, they complains, why it is difficult to give guidance to get things that positively, that is it for them that really hard. .. ".

Based on the above opinion can be seen that in addition to laziness, motivation and enthusiasm of children to positive activities such as learning or training is still lacking. In addition, the obstacles of the managers themselves that is difficult to condition the child to follow the programs and activities that exist because of the high mobility of children. Another internal inhibiting factor is the instant attitude in education. As stated by the leader of the shelter house, Mr. Syd: "... .. Well that's the children there. It was not strong until the high school education, most junior high school, the most rarely entered, then we try to pursue 
the program of kejar paket, that the children also wants it instantly by asking to be guided by the tutor and ask for graduation, they do not get the knowledge that he can but only something that is formal legal like a diploma, it did not educate them ..." .

As for the external inhibiting factor comes from the family. Children's family participation in children's education is lacking. This is due to lack of ability and understanding of family-related educational problems, but also because of family economic problems, and not infrequently there are families who are not concerned with the fate of children. As expressed by Mr. Syd, the leader of the shelter house: If the participation of the family, most of the $100 \%$ that is globally it $70 \%$ already assume he was lost, yo syukur, ora yo syukur ilang endok e siji. It means that they can be is good, if it is not that only lose one child. Mostly like that. Yes there are families who have come here, but in terms of his ability to provide education, a comfortable place that can not be, so the children let alone get it. Some mellows are too many. Yesterday we try to reunification to ask some question there, I go to the children's house, we survey, it turns out his mother refused, biological mother ".

Based on some opinions above that can be seen in dealing with and implementing activities especially education assistance, Shelter House Ahmad Dahlan has internal and external factors. Internal inhibiting factors are derived from the street children themselves, ie one of the motivation of children to return normatively is still low. While external factors derived from the children's family.

\section{Conclusions}

Based on the formulation of the problem, the results of research and discussion, and research findings that have been done, it can be concluded as follows: 1. Implementation of street children education in shelter house:

a. In overcoming the problems of street children, Puri Indah Shelter House of Sidoarjo, has the same stage which consists of five stages, outreach stage, entrance stage of the shelter house, preparation phase of mentoring, acceptance of mentoring, and the termination of mentoring.

b. In carrying out the management, both the leaders of shelter house, social workers, educators and administrative personnel at the Puri Indah Shelter House of Sidoarjo have carried out their duties and responsibilities.

c. Factors supporting and inhibiting the implementation of street children education: 1). Shelter House Ahmad Dahlan; Supporting factors in the implementation of street children education in the shelter is that there are children who want to learn, the fulfillment of educational infrastructure facilities, the involvement of volunteers, community, schools, and government in the implementation of street children education. While the inhibiting factors of children are not normative, high mobility, lack of motivation, instant nature in education, laziness of children in following activities, and family participation is minimal.

2. Effectiveness Education pattern of street children in shelter home: 
a. Puri Indah Shelter House of Sidoarjo

The implementation of street children's education in Puri Indah Shelter House of Sidoarjo where has not been reached effectively, because of the five components of street children education in shelter can only achieve two standards, namely the standard of educators and educators, as well as infrastructure facilities. As for the standards of educational purposes, learners, and educational content has not been achieved effectively that do not contribute directly to children on the street because it inhibits the independence of children and accept the presence of children.

3. For Social Services and DIKPORA, it is better to review the standard of education of street children. Relevant agencies should provide guidance and direction to the manager of shelter, and provide assistance in shelter, especially in the implementation of street children education. The relevant offices should be directly involved in the implementation of education and socialization to the community about shelter and the importance of street children education pattern.

\section{Bibliography}

Arikunto, Suharsismi, Suhardjono, Supardi,Penelitian Tindakan kelas, Jakarta: Bumi Aksara, Cet. VI, 2008 .

Arikunto, Metode penelitian Kualitatif, Jakarta : Bumi Aksara, Cet V, 1996.

Zurinal, Ilmu Pendidikan, Pengantar dan dasar dasar pelaksanan Pendidikan,Jakarta : UIN Jakarta press, Cet. I, 2006.

De Moura,S. L "The sosial contructiaon of the street chlidren: aconfiguration implication" Britisth Journal of social Work :2002.

E. Mulyana, Manajemen berbasis

kopetensi dan aplikasinya, bandung :Rosdakarya, 2003.

Arikunto, Suharsimi. Prosedur Penelitian Suatu Pendekatan Praktik. Jakarta: Bumi Aksara. 2002.

Bungin, Burhan. Metodologi Penelitian Sosial: Format-Format Kuantitatif dan Kualitatif. Surabaya: Airlangga University Press. 2001.

Hamidi, Jazim. Metode Penelitian Kualitatif. Malang: UMMP Press. 2004.

International Programme on the Elimination of Child LaborInternational Labor Organization (ILO-IPEC Rahayu, Sugeng. Peran Keluarga Miskin Dalam Pendidikan Anak.Semarang: Unnes Press. 2006.

Kalida, M. Sahabatku Anak Jalanan. Yogyakarta: Alif Press. 2005.

Milles dan Huberman. . Metode Penelitian Kualitatif. Jakarta: Gramedia. 2002.

Moleong, Lexy J. Metode Penelitian Kualitatif. Bandung: Remaja Rosdakarya. 2007.

Moleong. Lexy J. Metode Penelitian kualitatif. Bandung : PT. Remaja Rosdakarya. 2006.

Pratomo, ES. Ghifari Suatu Pengentasan Anak Jalanan : Suatu Pendekatan Kualitatif. Humanitas. Vol.I. No.2. Agustus. 2004.

Putranto Puji. . Penanggulangan Pekerja Anak dan Pembangunan Masyarakat Desa. 1996.

Soemitra. Aspek Hukum Perlindungan

Anak. Jakarta: Bumi Aksara. 2000 